\title{
SUB-LETHAL POISONING OF POSSUMS WITH ACUTE PESTICIDES USED IN BAIT STATIONS
}

\author{
R.J. HENDERSON and G.A. MORRISS \\ Manaaki Whenua - Landcare Research, PO Box 69, Lincoln, New Zealand
}

\begin{abstract}
Cage and field evaluations showed that the percentage of possums sub-lethally dosed increased as baits became less palatable or the concentration of toxicant was reduced. Palatability was impaired when cereal-based baits were stored wet and this reduced the average kill. Lowering the concentration of 1080 or cholecalciferol in baits also resulted in lower kills. Toxic cereal baits should provide effective possum control when used in bait stations if they contain either $0.8 \%$ cholecalciferol or $0.15 \% 1080$, are highly palatable, and are kept dry until possums feed on them.
\end{abstract}

Keywords: Bait, palatability, toxicant, sub-lethal poisoning, possums

\section{INTRODUCTION}

It is still commonplace for $15 \%$ or more of possums to survive a major aerial control operation despite extensive research to identify reasons for survival (Morgan et al. 1986; Morgan 1994). Delivery of acute pesticides to possums by bait stations is more controlled, but $15 \%$ or more of possums may also survive this approach (Thomas et al. in press).

Possums sub-lethally poisoned during control operations become "shy" towards bait (Hickling 1994; Morgan et al. 1995) as a result of disturbances to normal physiological homeostasis during 1080 toxicosis (Atzert 1971). Shy possums will not eat enough bait to cause death for at least a further year (O'Connor 1994). Therefore, added to the cost of the initial failure are the compounded costs and technical difficulties of poisoning possums that have become reluctant to eat toxic baits. This makes it difficult for managers to maintain possum populations at the low densities needed to eradicate tuberculosis or reduce possum impacts on forest ecosystems.

This paper describes the extent to which two aspects of bait quality contribute to the sub-lethal poisoning of possums feeding from bait stations. Baits that varied in palatability or toxin concentration were tested initially on caged possums, then on wild possums.

\section{MATERIALS AND METHODS \\ Cage tests of palatability of cholecalciferol baits}

Possums were captured in locations close to where field evaluations were subsequently carried out. They were weighed and then acclimatized to captivity at the Landcare Research animal facility at Rangiora. Only animals with stable or increasing body weights after 4 four weeks in captivity were used for assessing bait palatability. Palatability was determined using a standard "two-choice" test (Grote and Brown 1971), in which a minimum of 15 individually caged possums were given paired trays containing $100 \mathrm{~g}$ of toxic cereal bait and $100 \mathrm{~g}$ of non-toxic cereal bait (as a control). The test and control baits appeared similar, both were made using the RS5 bait formulation (Animal Control Products, Waimate) and both contained $0.5 \%$ cinnamon. Palatability was calculated as the weight of test bait eaten expressed as a percentage of the total bait eaten (i.e., test and control baits). A value of $50 \%$ therefore indicates that the test bait was of equal palatability to the control. 
Four different cholecalciferol cereal baits were tested for palatability:

1) "Standard" toxic baits contained $0.8 \%$ cholecalciferol, $0.5 \%$ cinnamon, $10 \%$ calcium carbonate and less than $14 \%$ total moisture.

2) "Damp" bait was made by adding 6\% excess water to standard bait.

3) "Degraded" baits were made by storing damp baits at ambient temperatures of 10$35^{\circ} \mathrm{C}$ for 2 weeks.

4) "Chalky" baits were made by including calcium carbonate at $20 \% \mathrm{wt} / \mathrm{wt}$ in pilot batches of toxic bait (twice the concentration finally recommended for standard bait).

The amount of each bait type eaten by caged possums was compared by analysis of variance. Differences in mortality between the four groups were determined by nonoverlapping $95 \%$ binomial confidence intervals.

As the lethality of baits that contain a recommended concentration of toxicant is generally high when palatability exceeds $40 \%$, but is low when palatability is less than $30 \%$ (Landcare Research unpublished data), results from a wider range of trials on cholecalciferol baits were pooled into two palatability groupings. These included the datasets from the trials described above and two further sets in which cinnamon was included at a lower concentration $(0.1 \%)$ that would not mask the taste of the toxin, or in which the cinnamon was substituted with orange to make baits with a different flavour. The amount of bait of low palatability $(<30 \%)$ and high palatability $(>40 \%)$ that was eaten was compared by analysis of variance, and differences in the percentage of possums sub-lethally dosed were determined by non-overlapping $95 \%$ binomial confidence intervals.

\section{Cage tests of 1080 and cholecalciferol baits with varying toxicant concentrations}

The efficacy of toxic baits containing $0.15 \%$ or $0.08 \% 1080$, or $0.8 \%$ or $0.6 \%$ cholecalciferol was tested using caged possums. Although RS5 was chosen as the bait for cage and field trials, 30 additional possums were given No.7 bait (Animal Control Products, 408 Heads Rd., Wanganui) to increase numbers ingesting $0.08 \% 1080$ in cereal bait. Prior to cage trials, the concentration of toxicant in each sample was verified using a gas-liquid chromatography method for determination of 1080 (Okuno et al. 1982) and liquid chromatography for cholecalciferol (Gehrig and Stringham 1987). All baits tested had a palatability of $>40 \%$. For the efficacy trials, the caged possums were provided with $100 \mathrm{~g}$ of toxic bait and ad libitum alternative foods (a cereal ration and apple) for 16 hours overnight. The weight of toxic bait that was consumed was measured the following day. Possums that ate toxic baits were monitored for 4 weeks to establish the percentage surviving exposure to each bait type. Differences in mortality between groups was determined by non-overlapping binomial confidence intervals.

\section{Field trials}

The efficacy of 1080 and cholecalciferol baits with differing palatability and toxicant concentrations was further evaluated in replicated field trials carried out in discrete plantations (9-40 ha) of radiata pine in Canterbury. The pre-poison abundance of possums in the forest plantations was estimated using 100 Victor No.1 leg-hold traps that allow possums to be caught and released without significant injury. Traps were placed at 20-30 m intervals on sites where they were most likely to catch possums, and spaced so that there were no more than 7 traps/ha. The percentage of traps catching possums during two fine nights was recorded before toxic baits were presented.

Bait stations were then distributed at the recommended density of approximately 1/ha (Thomas et al. in press). Most of the bait stations were placed around the edge of each forest block, approximately $100 \mathrm{~m}$ apart, although some were also placed within the forest to ensure that bait was readily accessible to all possums. The bait stations each contained $200 \mathrm{~g}$ of toxic cereal bait, and were visited at intervals of 1-2 weeks over a period of 5 weeks to measure and replace the bait that had been eaten. Previous trials have shown that all possums are exposed to bait within 5 weeks using this baiting strategy (Henderson et al. 1994; Thomas et al. in press). 
On completion of each field trial, a post-poison estimate of possum abundance was made by setting traps for 2 consecutive nights in the same locations as before. The percentage of the population killed was estimated from the percentage decline in the proportion of traps catching possums. The influence of bait palatability and toxicant concentration on percentage kill was determined by analysis of variance.

\section{RESULTS}

Laboratory assay of baits before cage and field trials showed that the measured concentration of toxicant in all baits was within $\pm 10 \%$ of the nominal concentration of 1080 and $\pm 7 \%$ of the nominal concentration of cholecalciferol (i.e., the concentrations all fell within the stated precision of the method of analysis).

\section{Cage tests of palatability of cholecalciferol baits}

The palatability to caged possums of "chalky" and "degraded" baits was about half that of "standard" baits (Table 1). This decrease in palatability significantly reduced the consumption of both bait types $(\mathrm{F}=7.4$, d.f. $=3, \mathrm{P}<0.01)$ and consequently increased the proportion of possums that were sub-lethally dosed $(\mathrm{P}<0.05)$. Although bait that was "damp" for 1 day was more palatable than standard bait, this difference did not significantly increase the amount of bait eaten $(\mathrm{P}>0.05)$.

TABLE 1: The effect of bait palatability on the percentages of captive and wild possums killed by baits containing $0.8 \%$ cholecalciferol.

\begin{tabular}{|c|c|c|c|c|}
\hline \multirow[t]{2}{*}{ Bait type $^{1}$} & \multicolumn{3}{|c|}{$\begin{array}{l}\text { Captive possums killed by eating bait } \\
\text { of differing palatability }\end{array}$} & \multirow{2}{*}{$\begin{array}{l}\text { Percentage of } \\
\text { possums killed } \\
\text { in field trials }\end{array}$} \\
\hline & $\begin{array}{l}\text { Palatability } \\
\text { of bait } \\
(\%)\end{array}$ & $\begin{array}{l}\text { Average amount } \\
\text { of bait eaten } \\
\text { (95\% C.I.) }\end{array}$ & $\begin{array}{l}\text { Percentage } \\
\text { of possums } \\
\text { killed }\end{array}$ & \\
\hline Standard & 41.1 & $17.6 \mathrm{~g} \mathrm{(4.8)}$ & $\begin{array}{c}95 \% \\
(20 / 21)\end{array}$ & $\begin{array}{c}87 \% \\
(\text { range }=80-97 \%) \\
(n=3)\end{array}$ \\
\hline $\begin{array}{c}\text { Damp } \\
\text { (for } 1 \text { day) }\end{array}$ & 51.4 & $20.2 \mathrm{~g}(5.7)$ & $\begin{array}{c}87 \% \\
(27 / 31)\end{array}$ & $\mathrm{NA}^{2}$ \\
\hline $\begin{array}{c}\text { Degraded } \\
\text { (damp for } \\
2 \text { weeks) }\end{array}$ & 24.8 & $8.1 \mathrm{~g}(2.7)$ & $\begin{array}{c}55 \% \\
(23 / 42)\end{array}$ & $\begin{array}{c}48 \% \\
(\text { range }=43-54 \%) \\
(n=2)\end{array}$ \\
\hline $\begin{array}{c}\text { Chalky } \\
\left(20 \% \mathrm{CaCO}_{3}\right)\end{array}$ & 19.9 & $8.5(5.6)$ & $\begin{array}{l}47 \% \\
(7 / 15)\end{array}$ & $\begin{array}{l}46 \% \\
(n=1)\end{array}$ \\
\hline
\end{tabular}

${ }^{1}$ All bait contained $0.8 \%$ cholecalciferol $+0.5 \%$ cinnamon $+10 \% \mathrm{CaCO}_{3}$ unless otherwise stated

${ }^{2}$ Not Assessed

Palatability markedly affected the efficacy of baits containing cholecalciferol (Figs. 1a, 1b, 1c, 1d). Overall caged possums ate less $(\mathrm{F}=29.8$, d.f. $=1, \mathrm{P}<0.01)$ cholecalciferol bait of low palatability $(7.0 \mathrm{~g}$, s.e. $=0.76, \mathrm{n}=104)$ than bait of high palatability $(14.6 \mathrm{~g}$, s.e. $=1.2, \mathrm{n}=72)$, and more possums were sub-lethally dosed $(56 \%$ cf. $16 \%)$ as a consequence $(\mathrm{P}<0.05)$. Approximately $12.5 \mathrm{~g}$ of bait would be lethal to all possums in these cage and field trials (average weight $=2.7 \mathrm{~kg}$, S.D. $=0.6, \mathrm{n}=530$ ).

\section{Cage tests of 1080 and cholecalciferol baits with different toxicant concentration}

Both 1080 and cholecalciferol baits with less than the recommended amount of toxicant killed fewer caged possums than standard bait $(\mathrm{P}<0.05)$, (Table 2$)$. 

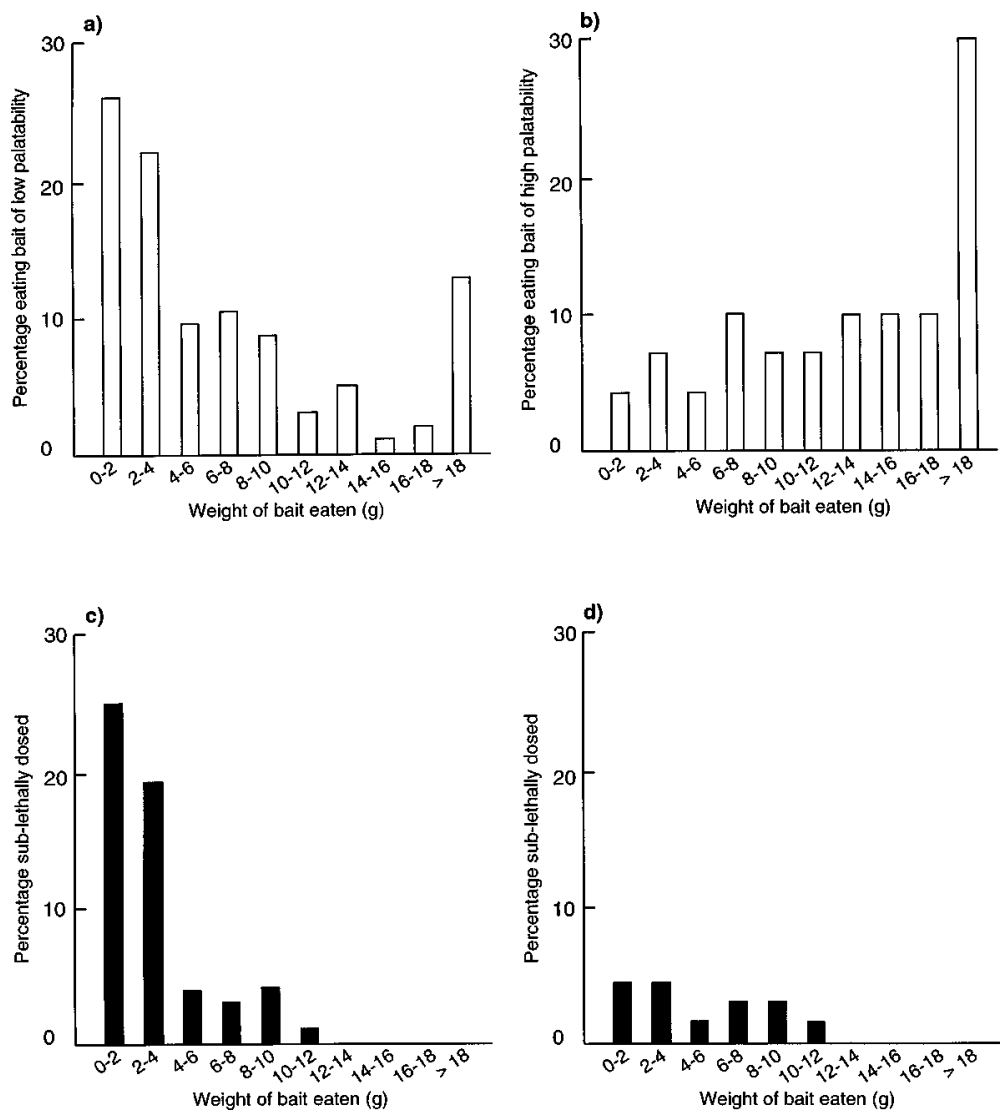

FIGURE 1: The distribution of cholecalciferol bait eaten that was of low palatability (1a, $n=104)$ and high palatability $(1 b, n=72)$. The percentages of each population sub-lethally dosed with each bait type are shown in 1c and 1d, respectively.

\section{Field trials}

When cholecalciferol baits with low palatability were used in field trials, the percentage of possums killed was significantly lower than with standard baits $(\mathrm{F}=15.2$, d.f. $=2, \mathrm{P}<0.05$ ). The percentages of wild possums surviving an exposure to biodegraded and chalky baits was similar. Use of degraded cholecalciferol baits in bait stations reduced the average kills in field trials from $87 \%$ to $48 \%$ (Table 1). These reduced kills (viz. 39\% fewer possums killed) coincided with a $39 \%$ decline in measured palatability from a value of $41.1 \%$ to $24.8 \%$.

Reducing the concentration of 1080 in bait from $0.15 \%$ to $0.08 \%$ significantly reduced the average kills in field trials $(\mathrm{F}=20.6$, d.f. $=1, \mathrm{P}<0.01)$ from $95 \%(\mathrm{n}=2)$ to $56 \%(n=6))$. Therefore, $39 \%$ fewer possums were killed when the concentration of 1080 in bait was reduced by $46 \%$. A $25 \%$ reduction in cholecalciferol from $0.8 \%$ to 
$0.6 \%$ resulted in an additional $23 \%$ of possums surviving poisoning, and this also caused a significant decline in field trial kills from $87 \%$ to $64 \%$ ( $\mathrm{F}=16.5$, d.f. $=1$, $\mathrm{P}<0.05)$ (Table 2).

TABLE 2: The percentage of captive and wild possums killed by baits containing different concentrations of toxin.

\begin{tabular}{|c|c|c|c|}
\hline \multirow[t]{2}{*}{ Bait type } & \multicolumn{2}{|c|}{$\begin{array}{l}\text { Captive possums killed } \\
\text { after eating toxic bait }\end{array}$} & \multirow{2}{*}{$\begin{array}{l}\text { Percentage of } \\
\text { possums killed } \\
\text { in field trials }\end{array}$} \\
\hline & $\begin{array}{l}\text { Average } \\
\text { amount of } \\
\text { bait eaten } \\
\text { (95\% C.I.) }\end{array}$ & $\begin{array}{l}\text { Percentage } \\
\text { of possums } \\
\text { killed }\end{array}$ & \\
\hline \multicolumn{4}{|c|}{ Baits containing cholecalciferol } \\
\hline Pry $0.8 \%$ cholecalciferol bait & $17.6 \mathrm{~g}(4.8)$ & $\begin{array}{c}95 \%(20 / 21) \\
(\text { range }=80-97 \%) \\
(n=3)\end{array}$ & $87 \%$ \\
\hline Pry $0.6 \%$ cholecalciferol bait & $13.1 \mathrm{~g}(4.9)$ & $\begin{array}{c}61 \%(20 / 33) \\
(\text { range }=63-66 \%) \\
(n=3)\end{array}$ & $64 \%$ \\
\hline \multicolumn{4}{|l|}{ Baits containing 1080} \\
\hline $.15 \% 1080$ in RS5 bait & $11.1 \mathrm{~g}(1.6)$ & $\begin{array}{c}93 \%(80 / 86) \\
(\text { range }=91-100 \%) \\
(n=2)\end{array}$ & $95 \%$ \\
\hline $0.08 \% 1080$ in RS5 bait & $11.7 \mathrm{~g}(9.8)$ & $\begin{array}{c}60 \%(3 / 5) \\
(\text { range }=44-75 \%) \\
(n=6)\end{array}$ & $56 \%$ \\
\hline $.08 \% 1080$ in No.7 bait & $9.9 \mathrm{~g}(4.5)$ & $63 \%(19 / 30)$ & $\mathrm{NA}^{1}$ \\
\hline
\end{tabular}

${ }^{1}$ Not Assessed

\section{DISCUSSION}

The amount of toxicant ingested by possums in both cage and field trials was often reduced to sub-lethal levels either by reducing how much bait they ate (i.e., lowering palatability), or by reducing bait toxicity (i.e., lowering the concentration of toxicant). Reducing the palatability of bait by $39 \%$ reduced the percentage of wild possums killed with cholecalciferol baits from $87 \%(n=3)$ to $48 \%(n=2)$. Lowering the concentration of 1080 in baits from $0.15 \%$ to $0.08 \%$ reduced the average kill in field trials from $95 \%(n=2)$ to $56 \%(n=6)$, and lowering cholecalciferol from $0.8 \%$ to $0.6 \%$ reduced kills from $87 \%(n=3)$ to $64 \%(n=3)$. To ensure that few possums are sublethally poisoned during control operations using bait stations, cereal baits must be of an assured quality, exceeding minimum thresholds of both palatability (i.e., $>40 \%$ ) and toxic concentration (i.e., $+0.15 \% 1080$ or $+0.8 \%$ cholecalciferol).

Cereal baits of assured quality will lose efficacy if they become damp. Because cereal baits are hygroscopic, they readily absorb moisture when stored in a damp place, or when used in conditions of high humidity in the field. Although baits remain palatable for a day after they have absorbed moisture, our trials show that use of such baits is likely to cause an increasing proportion of possums to be sub-lethally poisoned as they degrade during the following two weeks. Previous research has also shown that fewer rodents are killed as rodenticides become damp and less palatable, and it was recommended that wax or ethylene polymers be added to cereal-based baits to prevent them absorbing atmospheric moisture (Twigg and Kay 1992). Cereal baits without a water repellent become wet when directly exposed to rain, and 1080 is rapidly leached from them (Bowen et al. 1995). Associated with this loss in toxicity will be an increase in sub-lethal poisonings. 
Minimizing the amount of sub-lethal poisoning that occurs in possum control operations will not only improve operational effectiveness but will also help reduce bait shyness in the residual population. Bait palatability and toxicant concentration are therefore vitally important factors that must be routinely checked as part of the quality assurance process to ensure successful operations.

\section{ACKNOWLEDGEMENTS}

We thank the Selwyn Plantation Board and farmers who made areas available for field trials. Hugh Fitzgerald assisted with fieldwork. Dave Morgan, Mark Wickstrom, Joanna Orwin and Megan Ogle-Mannering provided editorial advice and comments. The Foundation for Research, Science and Technology funded the research as part of a programme entitled Integrated Management of Vertebrate Pests (CO9307). The Animal Health Board also funded the cholecalciferol field trials as part of a programme to develop new possum pesticides.

\section{REFERENCES}

Atzert, S.P., 1971. A review of sodium monofluoroacetate (compound 1080), its properties, toxicology, and use in predator and rodent control.US Fish Wildl. Serv. Bur. Sport Fish. Wildl. Special Scientific Report - Wildlife No.146. 34p.

Bowen, L.H., Morgan, D.R., and Eason, C.T., 1995. Persistence of sodium monofluoroacetate (1080) in baits under simulated rainfall.N.Z. J. Agric. Res. 38: 529-531.

Gehrig, C.C. and Stringham, R.W., 1987. Liquid chromatography determination of cholecalciferol in rodenticide baits. J. Off. Anal. Chem. 70: 1058-1059.

Grote, F.W. and Brown R.T., 1971. Conditioned taste aversions: two stimulus tests are more sensitive than one-stimulus tests. Behav. Res. Methods Instru. 3: 311-312.

Henderson, R.J., Frampton, C.M., Thomas, M.D. and Eason, C.T., 1994. Field evaluations of cholecalciferol, gliftor, and brodifacoum for the control of brushtail possums (Trichosurus vulpecula). Proc. 47th N.Z. Plant Prot. Conf: 112-116.

Hickling, G.J., 1994. Behavioural resistance by vertebrate pests to 1080 toxin: implications for sustainable pest management in New Zealand. Pp 151-158 In: Proceedings of the Science Workshop on 1080., A.A. Seawright and C.T. Eason (Eds); The Royal Soc. N.Z. Misc. Ser. 28.

Morgan, D.R., Batcheler, C.L. and Peters J.A., 1986. Why do possums survive aerial poisoning operations? Proc. 12th Vert. Pest Conf. San Diego, California: 210214.

Morgan, D.R., 1994. Improved cost-effectiveness and safety of sodium monofluoroacetate (1080) possum control operations. Pp 144-150In: Proceedings of the Science Workshop on 1080., A.A. Seawright and C.T. Eason (Eds); The Royal Soc. N.Z. Misc. Ser. 28.

Morgan, D.R., Meikle, L. and Hickling, G.J., 1995. Induction, persistence, and management of 1080 bait "shyness" in captive brushtail possums.Proc. 10th Aust. Vert. Pest Conf., Hobart, Australia: 328-332.

O’Connor, C.E. 1994. Bait shyness in possums. N.Z. Ecol. Soc. Newsletter No.75: 14.

Okuno, I., Meeker, D.L. and Felton, R.R., 1982. Modified gas-liquid chromatographic method for determination of compound 1080. Sodium Fluoro. 65(5): 1102-1105.

Thomas, M.D., Henderson R.J. and Hickling, G.J., (in press). Optimising possum control using bait stations. In: Proc. NSSC Workshop on Conventional Control of Possums, Wellington, Dec. 1995.

Twigg, L.E. and Kay, B.J., 1992. Evaluation of Quintox ${ }^{\circledR}$ for control of feral house mice. J.Wildl. Manage. 56(1): 174-185. 